\title{
PENGARUH CURRENT RATIO, DEBT TO EQUITY RATIO DAN NET PROFIT MARGIN TERHADAP RETURN SAHAM PADA PERUSAHAAN KOSMETIK DAN BARANG KEPERLUAN RUMAH TANGGA YANG TERDAFTAR DI BURSA EFEK INDONESIA PERIODE 2012-2017
}

\author{
Nalindri Arin Fatansiru \\ arinnew666@gmail.com \\ Universitas Ahmad Dahlan \\ Candra Vionela Merdiana \\ candra.vm@mgm.uad.ac.id \\ Universitas Ahmad Dahlan
}

\begin{abstract}
ABSTRAK
This study aims to analyze the effect of Current Ratio, Debt toEquity Ratio, and Net Profit Margin on stock returns of case studies in companies cosmetics and household goods listed on the Indonesia Stock Exchange period 2012-2017 Independent variables used in this study are Current Ratio, Debt to Equity Ratio, and Net Profit Margin while the dependent variable is stock returns. The population in this study is all cosmetics and household goods companies for the period 2012-2017. Based on the purposive sampling method obtained 5 samples. Data type used is secondary data. Data obtained by the method of documentation. The analysis technique used is the Panel Data Regression Analysis. The results of multiple linear regression analysis with a significant level of 5\%, then it can concluded that the first hypothesis Current Ratio of 0.02 has a negative effect and significant towards stock returns, the second hypothesis is Debt to Equity Ratio of 0.90 positive and not significant effect on stock returns, the third hypothesis is Net Profit Margin of 0.08 has no effect on stock returns, hypotheses fourth, Current Ratio, Debt to Equity Ratio, and Net Profit Margin of 0.015726 simultaneously affect stock returns.
\end{abstract}

Keywords: Current Ratio, Debt to Equity, Net Profit Margin, Stock Return.

\begin{abstract}
PENDAHULUAN
Pada saat ini banyak perusahaan yang menggunakan pasar modal sebagai tempat untuk memperoleh tambahan dana, hal ini tidak terlepas dari peran para investor yang melakukan transaksi dipasar modal sehingga mendorong perusahaan yang sudah go public untuk menjual sebagian sahamnya kepada investor. Sebelum melakukan pembelian saham para investor terlebih dahulu melakukan penilaian dengan baik terhadap perusahaan yang akan dibeli sahamnya sehingga para investor dapat
\end{abstract}

mengetahui tingkat pengembalian (return) saham yang akan dibelinya. Dengan memperdagangkan sahamnya di pasar modal, maka perusahaan dapat memperoleh dana bagi kelangsungan hidup perusahaan.

Di pasar modal harga saham suatuperusahaan dapat dijadikan sebagai salah satu tolak ukur baik tidaknya kinerja keuangan perusahaan tersebut,sehingga dapat dikatakan dalam kondisi yang wajar dan normal, semakin baik kinerja keuangan suatu perusahaan harga sahamnya juga semakin membaik atau meningkat. Dengan melonjaknya jumlah saham yang ditransaksikan, dan semakin tingginya volume perdagangan saham 
akan mendorong perkembangan pasar modal di Indonesia.

Pada hakikatnya, seorang investor melakukan investasi dengan harapan untuk investasinya tersebut mampu memberikan tingkat pengembalian yang diharapkan. Investasi di Bursa Efek Indonesia merupakan jenis investasi dengan resiko relatif tinggi meskipun menjanjikan keuntungan yang relatif besar. Harapan keuntungan dimasa datang merupakan atas waktu dan risiko yang terkait dengan investasi yang dilakukan. Dalam konteks investasi, harapan keuntungan tersebut sering disebut return. Tingkat return merupakan rasio antara pendapatan investasi selama beberapa periode dengan jumlah dana yang diinvestasikan.

Salah satu cara yang biasa digunakan dalam menilai perusahaan adalah pendekatan fundamental. Pendekatan tersebut terutama ditujukan kepada faktorfaktor yang pada umumnya berada diluar pasar modal, yang dapat mempengaruhi harga saham di masamasa mendatang. Hal-hal yang termasuk dalam analisis fundamental diantaranya adalah analisis ekonomi dan industri, penilaian perusahaan secara individu baik dengan menggunakan variabel penelitian seperti deviden maupun pendapatan.

Faktor fundamental dari perusahaan yang dapat menjelaskan kekuatan dan kelemahan kinerja keuangan perusahaan diantaranya adalah rasio-rasio keuangan. Melalui rasio-rasio keuangan kita bisa membuat perbandingan yang berarti dalam dua hal. Pertama, kita bisa membandingkan rasio keuangan suatu perusahaan dari waktu ke waktu untuk mengamati kecenderungan (trend) yang sedang terjadi. Kedua, kita bisa membandingkan rasio keuangan sebuah perusahaan dengan perusahaan lain yang masih bergerak disuatu sektor yang sama dengan periode tertentu.

Investor yang akan melakukan investasi dengan membeli saham dipasar modal akan menganalisis kondisi perusahaan terlebih dahulu agar investasi yang dilakukan dapat memberikan keuntungan (return). Memperoleh return merupakan tujuan utama dari aktivitas perdagangan para investor dipasar modal. Pola perilaku perdagangan saham dipasar modal dapat memberikan kontribusi bagi pola perilaku harga saham dipasar modal tersebut.

Return saham merupakan hasil yang diperoleh dari kegiatan investasi. Return dibedakan menjadi dua, yaitu return realisasi (return yang terjadi atau dapat juga disebut sebagai return sesungguhnya) dan expected return (return yang diharapkan oleh investor) (Jogiyanto, 2003).

Sub sektor perusahaan kosmetik dan barang keperluan rumah tangga merupakan bagian dari salah satu sektor industri barang konsumsi yang terdaftar di Bursa Efek Indonesia yang bergerak dalam produksi kosmetik, wangi wangian, perawatan rambut, produk makanan dan minuman, produk perawatan rumah, serta produk perawatan tubuh. Terdapat enam perusahaan yang bergabung menjadi anggota di Bursa Efek Indonesia dengan waktu yang tidak bersamaan pada sub sektor tersebut, diantaranya adalah PT. Kino Indonesia Tbk, PT. Akasha Wira International Tbk, PT. Mandom Indonesia Tbk, PT. Unilever Indonesia Tbk, PT. Martina Berto Tbk, dan PT. Mustika Ratu Tbk

Setiap perusahaan tersebut pastinya memulai usaha dengan tujuan untuk menghasilkan laba semaksimal mungkin dari kegiatan bisnisnya, perusahaan perusahaan tersebut berusaha membuat inovasi produk terbaru agar menarik perhatian kosumen sehingga membeli dan menggunakannya disamping itu juga untuk memenangkan persaingan dengan perusahaan yang bergerak dalam bidang sejenis. Masing-masing produk yang diproduksi oleh perusahaan kosmetik dan 
barang keperluan rumah tangga yang terdaftar di Bursa Efek Indonesia sudah banyak dikenal oleh masyarakat luas bahkan sudah banyak digunakan secara rutin dan hanya beberapa saja yang masyarakat masih merasa asing. Jika dilihat dari hal tersebut maka tidak heran jika persaingan yang terjadi antar perusahaan yang sejenis sangatlah kuat untuk menghasilkan laba tertinggi. Namun pada kenyataannya meskipun terlihat baik-baik saja sebenarnya komponen laba bersih periode 2011 menuju 2016 cenderung mengalami penurunan yang menyebabkan beberapa perusahaan kosmetik dan barang keperluan rumah tangga mengalami penurunan laba bersih pada tahun 2016. Perusahaan yang mengalami penurunan laba bersih pada tahun 2016 diantaranya adalah PT. Mandom Indonesia yang disebabkan oleh menurunnya laba sebelum pajak dan pada PT. Mustika Ratu Tbk terjadi penurunan terhadap penjualan bersih laba bruto, laba usaha dan laba sebelum pajak. Sedangkan perusahaan lainnya yang mengalami peningkatan yaitu PT. Akasha Wira International Tbk, PT. Martina Berto Tbk dan PT. Unilever Indonesia Tbk. Perusahaan yang memperoleh laba bersih terendah di tahun 2016 yaitu PT. Mustika Ratu Indonesia Tbk dengan perolehan -5.549.465.678.

Laba bersih merupakan salah satu tolak ukur keberhasilan perusahaan dalam pencapaian tujuannya, selain itu laba bersih menjadi salah satu komponen dalam mengukur kinerja keuangan perusahaan baik atau tidaknya kondisi keuangan perusahaan tersebut. Kondisi keuangan perusahaan dapat dipantau dengan cara analisis kinerja keuangan perusahaan, maksudnya yaitu kegiatan memantau bagaimana kondisi perusahaan tersebut dari sisi keuangan, masing-masing perusahaan memiliki parameter kinerjanya sendiri. PT. Unilever Indonesia Tbk membukukan pertumbuhan laba bersih tertinggi di antara perusahaan lainnya, sepanjang semester 1/2013 perusahaan berkode saham UNVR tersebut berhasil mengalami pertumbuhan laba bersih sebesar $21,7 \%$ menjadi $\mathrm{Rp}$ 2,8 triliun. Posisi kedua ditempati oleh PT. Mandom Indonesia Tbk dengan mencetak pertumbuhan laba bersih 2,63 menjadi Rp 78 miliar. Perusahaan berkode saham TCID tersebut juga mencatat pertumbuhan penjualan sebesar 3,7\% atau setara dengan Rp 989 miliar. Sementara itu, dua perusahaan kosmetik dalam negeri yaitu PT. Martina Berto Tbk (MBTO) dan PT. Mustika Ratu Tbk (MRAT) selama semester 1/2013 mengalami penurunan laba bersih. Laba bersih PT. Martina Berto Tbk turun 25\% setara Rp 18 miliar, padaha angka penjualan meningkat 2,4\% menjadi Rp 337 miliar. Adapun laba bersih MRAT turun $22 \%$ menjadi Rp 10,4 miliar dengan penurunan penjualan sebesar 4,3\% menjadi Rp 197 miliar.

Beberapa penelitian sebelumnya yang berkaitan tentang pengaruh kinerja keuangan terhadap return saham diantaranya yang telah dilakukan oleh Rachmawan (2011) membuktikan bahwa secara simultan DER dan NPM berpengaruh signifikan terhadap return saham. Secara parsial yang berpengaruh signifikan terhadap return saham yaitu NPM. Penelitian lain dilihat dari Marpaung (2012) membuktikan bahwa secara simultan DER dan NPM tidak berpengaruh signifikan terhadap return saham, secara parsial pun tidak berpengaruh signifikan terhadap return saham.

Berdasarkan hasil penelitian tersebut, membuktikan bahwa masih adanya ketidak konsistenan hasil penelitian-penelitin ini. Hal ini mendorong peneliti untuk melakukan 
penelitian lebih lanjut mengenai pengaruh kinerja keuangan terhadap return saham dengan rasio likuiditas (current ratio), rasio leverage (debt to equity ratio) dan rasio profitabilitas (net profit margin).

Current Ratio (CR) adalah rasio yang mengukur kemampuan aktiva lancar perusahaan dalam memenuhi kewajiban jangka pendek dengan aktiva lancar yang dimiliki. Debt To Equity Ratio (DER) merupakan perbandingan antara total hutang (hutang lancar dan hutang jangka panjang) dan modal yang menunjukkan kemampuan perusahaan untuk memenuhi kewajibannya dengan menggunakan modal yang ada. Semakin tinggi DER menunjukkan semakin besar total hutang terhadap ekuitas (Ang, 1997) juga akan menunjukkan semakin besar ketergantungan perusahaan terhadap kreditur sehingga tingkat resiko perusahaan semakin besar. Hal ini akan berdampak pada menurunnya harga saham dibursa efek, sehingga return saham akan turun. Net Profit Margin (NPM) merupakan perbandingan antara pendapatan bersih dengan pendapatan operasi. Net Profit Margin ini berfungsi untuk mengukur tingkat kembalian keuntungan bersih terhadap penjualan bersih. Menurut Ang (1997) semakin besar nilai Net Profit Margin berarti semakin efisien biaya yang dikeluarkan yang berarti semakin besar tingkat kembalian keuntungan bersih. Menurut Ang (1997) semakin baik kinerja keuangan perusahaan yang tercermin dari rasio-rasionya maka semakin tinggi return saham perusahaan,demikian juga kondisi ekonomi baik maka refleksi harga saham akan baik pula.

Penelitian mengenai return saham telah banyak dilakukan mengingat pentingnya faktor fundamental dalam mempengaruhi nilai return saham. Namun berdasarkan bukti empiris yang menghubungkan faktor-faktor fundamental dengan return saham masih menunjukkan hasil yang berbeda-beda sehingga perlu dilakukan penelitian lebih lanjut untuk membuktikan bagaimana pengaruh Current Ratio, Debt to Equity Ratio, dan Net Profit Margin terhadap return saham terutama di sub sektor Kosmetik dan Barang Keperluan Rumah Tangga.

Tujuan dari penelitian ini antara lain: 1) untuk mengetahui pengaruh Current Ratio terhadap return saham pada perusahaan kosmetik dan barang keperluan rumah tangga yang terdaftar di Bursa Efek Indonesia, 2) untuk mengetahui pengaruh Debt to Equity Ratio terhadap return saham pada perusahaan kosmetik dan barang keperluan rumah tangga yang terdaftar di Bursa Efek Indonesia, 3) untuk mengetahui pengaruh Net Profit Margin terhadap return saham pada perusahaan kosmetik dan barang keperluan rumah tangga yang terdaftar di Bursa Efek Indonesia dan 4) untuk mengetahui pengaruh Current Ratio, Debt to Equity Ratio dan Net Profit Margin secara simultan terhadap return saham pada perusahaan kosmetik dan barang keperluan rumah tangga yang terdaftar di Bursa Efek Indonesia .

\section{REVIEW LITERATUR DAN HIPOTESIS}

\section{Landasan Teori}

\section{Return Saham}

Menurut Hartono (2003), return saham dapat dibedakan menjadi dua jenis, yaitu return realisasi (realized return) dan return ekspetasi (expected return). Return realisasi merupakan return yang sudah terjadi yang dihitung berdasarkan data historis. Return ekspetasi merupakan return yang 
diharapkan terjadi dimasa mendatang dan masih bersifat tidak pasti.

\section{Kinerja Keuangan}

Fahmi (2012) kinerja keuangan adalah suatu analisis yang dilakukan untuk melihat sejauh mana suatu perusahaan telah menjalankan perusahaan dengan menggunakan aturan-aturan pelaksanaan keuangan secara baik dan benar.

3. Rasio Keuangan

Menurut Simamora (2000) analisis rasio menunjukkan hubungan di antara pos-pos yang terpilih dari data laporan keuangan.

\section{Penelitian Terdahulu}

Rachmawan (2011) melakukan penelitian dengan judul pengaruh kinerja keuangan terhadap return saham pada perusahaan kosmetik dan peralatan rumah tangga 2009-2011 di BEI. Hasilnya secara simultan DER, TAT, EPSdan NPM berpengaruh signifikan terhadap return saham. Secara parsial yang berpengaruh signifikan terhadap returrn saham yaitu TAT.

Chadina (2014) melakukan penelitian dengan judul pengaruh kinerja keuangan perusahaan terhadap return saham (studi pada perusahaan otomotif dan komponen di Bursa Efek Indonesia Tahun 2010-2012). Hasilnya DER dan NPM tidak berpengaruh secara parsial terhadap return saham. Sedangkan current ratio berpengaruh signifikan terhadap return saham. Secara simultan berpengaruh terhadap return saham.

\section{Hipotesis}

H1: Current Ratio berpengaruh positif signifikan terhadap return saham.
H2: Debt to Equity Ratio berpengaruh positif signifikan terhadap return saham.

H3: Net Profit Margin berpengaruh positif signifikan terhadap return saham.

H4: Current Ratio, Debt to Equity Ratio dan Net Profit Margin secara simultan berpengaruh signifikan terhadap return saham.

\section{METODE PENELITIAN}

\section{Populasi dan Sampel}

Populasi adalah wilayah generalisasi yang terdiri atas obyek atau subyek yang mempunyai kualitas dan karakteristik tertentu yang ditetapkan oleh peneliti untuk mempelajari dan kemudian ditarik kesimpulannya (Sugiyono, 2009). Populasi yang diambil dalam penelitian ini adalah seluruh perusahaan manufaktur sub sektor perusahaan Kosmetik dan Peralatan Rumah Tangga yang terdaftar dalam Bursa Efek Indonesia periode 2012-2017.

Pemilihan sampel dalam penelitian ini menggunakan purposive sampling dengan tujuan agar diperoleh sampel yang representatif sesuai dengan kriteria yang ditentukan, adapun kriteria pemilihan sampel adalah sebagai berikut:

1. Perusahaan yang akan diteliti sebatas perusahaan Kosmetik dan Peralatan Rumah Tangga yang terdaftar di Burs Efek Indonesia pada periode tahun 2012 sampai dengan tahun 2017 secara terus menerus (tidak pernah di-delist).

2. Perusahaan memiliki data harga penutupan saham, dimana saham tersebut sahamnnya masih aktif di perdagangkan selama periode tahun 2012 sampai dengan 2017. 
3. Perusahaan tersebut mempunyai laporan keuangan yang telah di audit per 31 Desember selama periode tahun 2012 sampai dengan tahun 2017.

Sampel penelitian ini adalah lima perusahaan Kosmetik dan Peralatan Rumah Tangga yang terdaftar di Bursa Efek Indonesia dengantahun penelitian selama enam tahun yaitu dari tahun 20122017. Diantaranya PT. Unilever Tbk, PT. Mandom Indonesia Tbk, PT. Martina Berto Tbk, PT. Mustika Ratu Tbk, dan PT. Akhasa Wira International Tbk.

\section{Definisi Operasional}

1. Variabel Independen

Penelitian ini menggunakan return saham atau return total yaitu return keseluruhan dari suatu investasi dalam suatu periode tertentu.

2. Variabel Dependen

a. Current Ratio (CR)

Rasio ini menunjukkan sejauh mana aktiva lancar menutupi kewajiban-kewajiban lancar.

Semakin besar perbandingan aktiva dengan utang lancar semakin tinggi kemampuan perusahaan menutupi kewajiban jangka pendeknya.

b. Debt to Equity Ratio (DER)

Rasio ini menggambarkan hubungan antara hutang perusahaan terhadap modal. Rasio ini dapat melihat seberapa jauh perusahaan dibiayai oleh utang atau pihak luar dengan kemampuan perusahaan yang digambarkan oleh modal yang lebih besar dari utang (Harahap, 2008).

c. Net Profit Margin (NPM)

\begin{tabular}{|c|c|}
\hline Rasio & mengukur \\
\hline mampuan & perusahaan \\
\hline ghasilkan & bersih \\
\hline
\end{tabular}

perusahaan. Menurut Kasmir (2008), menyatakan bahwa Net profit Margin merupakan ukuran keuntungan yang membandingkan antara laba setelah bunga dan pajak dibandingkan dengan penjulan. Rasio ini menunjukkan pendapatan bersih perusahaan atas penjulan.

\section{Teknik Analisis Data}

1. Analisis Regresi Data Panel

Regresi linear data panel adalah model regresi yang memprediksi nilai satu variabel tunggal $\mathrm{Y}$ dengan nilai dasar nilai beberapa variabel bebas $\mathrm{X}$. Regresi linear berganda ini digunakan untuk menganalisis ketergantungan variabel dependen dengan variabel independen. Dalam penelitian return saham sebagai variabel dependen dan Current Ratio (CR), Debt to Equity Ratio (DER), Net Profit Margin (NPM) sebagai variabel independen. Model analisis regresi linear berganda dirumuskan sebagai berikut :

$\mathrm{Y}=\mathrm{a}+\mathrm{b} 1 \mathrm{X} 1+\mathrm{b} 2 \mathrm{X} 2+\mathrm{b} 3 \mathrm{X} 3$

Dimana :

Y : Return Saham

a : Konstanta

b1-b3 : Koefisien variabel Independen

$\mathrm{X} 1$ : Current Ratio

$\mathrm{X} 2$ : Debt to Equity Ratio

$\mathrm{X} 3$ : Net Profit Margin

2. Teknik Pemilihan Model Panel

a. Uji Chow

Pengujian Chow untuk menentukan apakah metode common effect atau fixed effect yang digunakan. Apabila Prob. chi square $<0,10$ maka fixed effect dan apabila Prob. chi square > 0,10 maka common effect. Jika keputusan menerima common effect, maka 
berhenti sampai common effect. Jika uji Chow menerima fixed effect maka dilanjut dengan pengujian random effect.

b. Uji Hausman

Asumsi yang terjadi dari data yang digunakan variabel dependen cenderung memiliki karakteristik yang tetap sepanjang waktu observasi ataukah mengandung adany perubahan-perubahan sepanjang waktu observasi (Ekanda, 2015). Random effect menggunakan uji Hausman apakah yang dipilih metode fixed effect atau random effect. Apabila Prob. Cross section random $<0,10$ maka fixed effect. Apabila Prob. Cross section random $>0,10$ maka random effect.

3. Uji Asumsi Klasik

a. Uji Normalitas

Dengan menggunakan uji normalitas untuk menguji apakah sampel penelitian yang digunakan berdistribusi normal atau tidak. Uji normalitas dapat dilakukan dengan bersamaan atau dapat dilakukan dengan satu persatu. Pada program eviews menggunakan program Jarque-Bera. Jarque-Bera adalah uji statistik untuk mengetahui apakah data berdistribusi normal atau tidak (Kusuma, 2012). Jika nilai prob J.B lebih besar dari $\alpha$ (prob J.B $>0,10$ ) maka data berdistribusi normal.

b. Uji Autokolerasi

Uji Autokorelasi adalah suatu hubungan antara residual observasi dengan observasi lain yang berlainan waktu (Widarjono, 2013). Autokorelasi diuji dengan uji Breusch-Godfrey. Uji Breusch yaitu jika Prpb. chiSquare $>0.10$ maka tidak ada autokorelasi dan jika prob. Chi Square > 0.10 artinya terjadi Autokorelasi.

c. Uji Heterokedastisitas

Uji Heteroskedastisitas adalah suatu gejala dimana residu dari suatu persamaan regresi berubahubah pada suatu rentang data tertentu (Ekananda, 2015). Metode yang digunakan adalah dengan Uji Breusch-PaganGodfrey. Apabila prob.chisquare (p-value) $>0,10(\alpha)$ maka tidak terjadi heteroskedastisitas dan jika prob chisquare (p-value) $<0,10(\alpha)$ maka terjadi heteroskedastisitas.

\section{d. Uji Multikolinearitas}

Uji multikolineritas digunakan untuk menguji apakah ada hubungan linear antara variabel independen dalam regresi. Uji multikolineritas digunakan untuk menguji apakah adanya hubungan yang erat antara variabel independen didalam suatu model regresi. Pada program eviews menggunakan regresi Ordinary Least Square (OLS) (Widarjono, 2013). Jika koefisien determinasi ( ) lebih dari 0.85 maka terjadi multikolineritas dan jika kurang dari 0.85 maka tidak terjadi multikolineritas. Apabila koefisien korelasi antara dua variabel bebas lebih besar 0.85 maka terjadi multikolineritas (Ekanda, 2015).

\section{Uji Hipotesis}

\section{a. Uji Parsial (Uji T)}

Uji hipotesis dilakukan dengan menggunakan uji t. Uji $t$ ini dilakukan untuk melihat pengaruh dari masing-masing variabel 
independen antara individu atau parsial terhadap variabel dependen (Widarjono, 2013). Uji ini dilakukan dengan membandingkan signifikansi t hitung dengan ketentuan sebagai berikut:

Jika nilai $\mathrm{t}$ hitung $<\mathrm{t}$ tabel maka $\mathrm{H} 0$ diterima.

Jika nilai $\mathrm{t}$ hitung $>\mathrm{t}$ tabel maka $\mathrm{H} 0$ ditolak.

Uji ini dilakukan dengan membandingkan nilai probabilitas signifikansi dengan ketentuan sebagai berikut:

Jika nilai probabilitas signifikansi $(\rho)<$ tingkat signifikansi $\alpha=0,05$ maka H0 ditolak.

Jika nilai probabilitas signifikansi ( $\rho)>$ tingkat signfikansi $\alpha=0,05$ maka H0 diterima.

\section{b. Uji Simultan (Uji F)}

Uji F dilakukan untuk menguji apakah model yang digunakan signifikan atau tidak, sehingga dapat dipastikan apakah model tersebut dapat digunakan untuk memprediksi pengaruh variabel bebas secara bersama-sama terhadap variabel terikat. Kriteria pengujiannya adalah jika $\mathrm{F}$ statistik > F tabel atau sig < 0,05 . Apabila telah memenuhi kriteria maka model dapat digunakan.

c. Uji Koefisien Determinasi

Uji Koefisien Determinasi (R2) Uji ini digunakan untuk menguji goodness-fit dari model regresi dimana untuk mengukur seberapa jauh kemampuan model dalam menerangkan variasi variabel terikat maka dapat dilihat dari nilai adjusted R2 (Widarjono, 2013).

\section{HASIL PENELITIAN DAN PEMBAHASAN}

\section{Hasil Penelitian}

1. Hasil Uji Regresi Data Panel

Hasil Uji Data Panel Random Effect

\begin{tabular}{|c|c|c|c|c|}
\hline Variabel & Coefficien & Prob. & 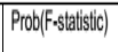 & $\begin{array}{l}\text { R.soquared } \\
\end{array}$ \\
\hline C & 0.4216125 & 0.61 & \multirow{4}{*}{0.015726} & \multirow{4}{*}{0.323877} \\
\hline Current ratio & -0.000598 & 0.02 & & \\
\hline Debt to Equity & 0.007450 & 0.90 & & \\
\hline Net Profit Margin & 0.011818 & 0.08 & & \\
\hline
\end{tabular}

Berdasarkan tabel di atas, dapat diketahui bahwa persamaan model estimasi adalah sebagai berikut:

Return saham = -4.216125$0.000598 \mathrm{CR}+0.007450 \mathrm{DER}+$ $0.011818 \mathrm{NPM}$

Persamaan model regresi dapat dijelaskan sebagai berikut:

a. Konstanta sebesar -0.4216125 artinya jika CR, DER, dan NPM nilainya konstan, maka nilai return saham sebesar 0.4216125

b. Koefisien regresi CR sebesar 0.000598 artinya jika CR naik sebesar satu satuan, maka return saham turun sebesar 0.000598 satuan. Sebaliknya jika CR turun satu satuan, maka return saham naik sebesar 0.000598 .

c. Koefisien regresi DER sebesar 0.007450 artinya jika DER naik satu satuan maka return saham naik sebesar 0.007450 . Sebaliknya jika DER turun satu satuan maka return saham turun sebesar 0.007450 . 
d. Koefisien regresi NPM sebesar 0.011818 , artinya jika NPM naik satuan maka return saham naik sebesar 0.011818. Sebaliknya jika NPM turun satu satuan maka return saham turun sebesar 0.011818 .

2. Hasil Pemilihan Model

a. Uji Chow

Hasil Uji Chow

\begin{tabular}{|l|l|}
\hline Effect test & Prob \\
\hline Cross-ection Chi-Square & 0.3022 \\
\hline
\end{tabular}

Hasil uji chow menunjukkan nilai Prob. Chi-Square sebesar 0.323 $>$ 0.05. Hasil ini menyimpulkan bahwa model fixed effect yang dipilih.

b. Uji Hausman

Hasil Lji Hausman
\begin{tabular}{|l|l|l|}
\hline Test summary & Chi-Square & Prob \\
\hline Cross-section Random & 3.424863 & 0.3306 \\
\hline
\end{tabular}

Hasil uji hausman menunjukkan nilai Prob. Cross section random sebesar $0.3306>0.05$. Dapat disimpulkan bahwa model yang tepat digunakan adalah model random effects.

3. Hasil Uji Asumsi Klasik

a. Hasil Uji Normalitas

Tabel Hasil Uji Normalitas

\begin{tabular}{|l|l|}
\hline Jarque-Bera & 0.746089 \\
\hline Probability & 0.688635 \\
\hline
\end{tabular}

Berdasarkan hasil tabel di atas, dapat disimpulkan bahwa residual persamaan regresi pada penelitian ini berdistribusi normal. Hal ini terlihat dari nilai prob J-B sebesar 0.688635 yang lebih besar dari alpha 5\% (0.05).

b. Hasil Uji Autokorelasi

Hasil Lji Autokorelasi

\begin{tabular}{|l|l|l|l|}
\hline F-Statistik & 0.314062 & Prob. F(2,24) & 0.7334 \\
\hline Obs*R-square & 0.765131 & Prob.Chi-Square & 0.6821 \\
& & $(2)$ & \\
\hline
\end{tabular}

Berdasarkan uji BreuschGodfrey Test menunjukkan nilai Prob. Chi-Square sebesar $0.6821>$ 0.05 maka dapat dikatakan data tidak terjadi autokorelasi.

c. Hasil Uji Heteroskedastisitas

Hasil Lji Heteroskedastisitas

\begin{tabular}{|l|l|l|l|}
\hline F-statistik & 2.57696 & Prob. F(3,16) & 0.0754 \\
\hline Obs*R-Square & 6.875451 & Prob. Chi-Square(3) & 0.0760 \\
\hline Scaler explained & 4.088850 & Prob. Chi-Square(3) & 0.250 \\
\hline
\end{tabular}

Berdasarkan hasil pemeriksaan terhadap gejala heteroskedastisitas dengan uji Breusch-Pagan-Godfrey (BPG) menunjukkan nilai Prob Chi-Square pada Obs*R-Square sebesar $0.0760>0.05$. Dapat disimpulkan bahwa tidak terjadi heteroskedastisitas.

d. Hasil Uji Multikolinieritas

Hasil Uji Multikolinieritas (koefisien korelasi)

\begin{tabular}{|l|l|l|l|}
\hline & Current Ratio & Debt to Equity & Net Profit Margin \\
\hline Current Ratio & 1.000000 & -0.404834 & -0.409701 \\
\hline Debt to Equity & -0.404834 & 1.000000 & 0.328703 \\
\hline Net Profit Margin & -0.308656 & 0.674981 & 0.461539 \\
\hline
\end{tabular}

Berdasarkan uji korelasi antar variabel independen di atas tidak 
terlihat adanya nilai korelasi (derajat keeratan) yang sangat tinggi 0.9 $(>90 \%)$ antara variabel independen. Variabel independen saling berkorelasi tidak lebih dari 0.9 (90\%) maka menunjukkan tidak terjadi adanya gejala multikolinieritas.

\section{Hasil Uji Parsial (Uji T)}

Uji t dilakukan untuk melihat apakah masing-masing variabel bebas memiliki berpengaruh terhadap variabel terikat. Kriteria pengambilan keputusan:

- H0 diterima jika nilai prob $>0.05$ artinya tidak ada pengaruh antara variabel independen dengan variabel dependen.

- H0 ditolak apabila nilai prob $<0.05$ artinya terdapat pengaruh antara variabel independen terhadap variabel dependen.

a. Variabel $\mathrm{CR}$ berpengaruh negatif dan signifikan terhadap return saham. Hal ini karena nilai prob < return saham, yaitu $0.02<0.05$ dan variabel $\mathrm{CR}$ berpengaruh negatif. Hal ini menunjukkan bahwa hipotesis yang mengatakan $\mathrm{CR}$ berpengaruh positif signifikan ditolak. Jadi dapat disimpulkan bahwa CR berpengaruh negatif signifikan terhadap return saham.

b. Variabel DER berpengaruh positif dan tidak signifikan terhadap return saham. Hal ini karena nilai prob > alpha yaitu $0.90>0.05$ dan variabel DER berpengaruh positif. Hal ini menunjukkan bahwa hipotesis yang mengatakan DER berpengaruh positif signifikan ditolak. Jadi dapat disimpulkan bahwa DER tidak berpengaruh signifikan terhadap return saham. c. Variabel NPM berpengaruh positif dan tidak signifikan terhadap return saham. Hal ini karena nilai prob> 0.05 yaitu $0.08>0.05$ dan variabel CR berpengaruh positif. Hal ini menunjukkan bahwa hipotesis yang mengatakan NPM berpengaruh positif signifikan ditolak. Jadi dapat disimpulkan bahwa NPM berpengaruh tidak signifikan terhadap return saham.

\section{Hasil Uji Simultan (Uji F)}

Uji koefisien regresi simultan digunakan untuk menguji hipotesis penelitian pengaruh simultan variabel bebas terhadap variabel terikat. Uji f digunakan untuk mengetahui kecocokan antara variabel bebas apakah berpengaruh signifikan secara serentak terhadap variabel terikat. Pengambilan keputusannya:

- jika tingkat signifikansi uji f $<0.05$, artinya terdapat pengaruh antara variabel

independen dan dependen secara simultan.

- jika tingkat signifikansi uji $\mathrm{f}>$ 0.05 , artinya tidak terdapat pengaruh antara

variabel independen terhadap variabel dependen secara simultan.

Berdasarkan hasil uji regresi, nilai prob. F statistik sebesar 0.015726 $<0.05$ artinya bahwa CR, DER, dan NPM secara simultan berpengaruh dan signifikan terhadap return saham pada perusahaan sub sektor kosmetik dan barang keperluan rumah tangga yang terdaftar di Bursa Efek Indonesia.

6. Hasil Uji Koefisien Determinasi

Koefisien determinasi (R2) digunakan untuk mengukur seberapa jauh kemampuan model menerangkan variasi dari variabel independen. 
Berdasarkan hasil uji regresi diketahui nilai R-Squared sebesar 0.323877 atau $32.3877 \%$. Hal ini menunjukkan bahwa variabel independen Current Ratio, Debt to Equity Ratio, dan Net Profit Margin dapat menjelaskan return saham sebesar $32.3877 \%$ sedangkan sisanya $67.6123 \%$ dijelaskan oleh variabel lain, diluar variabel dalam penelitian ini.

\section{Pembahasan}

1. Pengaruh Current Ratio Terhadap Return Saham.

Dari hasil uji parsial (uji t) diperoleh nilai probabilitas Current Ratio (CR) sebesar 0.02 dan koefisien sebesar -0.000598. Nilai probabilitas lebih kecil dari taraf signifikan 0.05 artinya Current Ratio berpengaruh negatif dan signifikan terhadap return saham. Current Ratio dapat menjadi indikator likuiditas yang baik jika persediaan tidak mudah dikonversi menjadi uang kas. Semakin besar angka CR maka semakin likuid kondisi perusahaan tersebut.

CR yang tinggi, yang berarti likuiditas yang tinggi juga menunjukkan bahwa perusahaan kurang mampu mengelola money to create money, yang pada akhirnya dapat mengurangi kemampuan perusahaan. Investor sering menilai bahwa semakin besar CR menunjukkan besarnya kemampuan perusahaan dalam memenuhi kebutuhan operasionalnya terutama modal kerja yang sangat penting untuk menjaga perfomance kinerja perusahaan yang pada akhirnya mempengaruhi performance harga saham. Hal ini dapat memberikan keyakinan kepada investor untuk memiliki saham perusahaan tersebut sehingga dapat meningkatkan return saham.
Current ratio merupakan rasio yang digunakan untuk mengukur seberapa kemampuan perusahaan untuk membayar kewajiban jangka pendek atau utang yang segera jatuh tempo pada saat ditagih secara keseluruhan. Menurut Sawir (2009) CR yang rendah biasanya dianggap menunjukkan terjadinya masalah likuidasi, sebaliknya CR yang terlalu tinggi juga kurang bagus, karena menunjukkan banyaknya dana menganggur yang pada akhirnya dapat mengurangi kemampuan perusahaan. Hasil ini didukung oleh Prihantini (2009) yang menunjukkan bahwa Current Ratio tidak berpengaruh secara signifikan terhadap return saham.

2. Pengaruh Debt to Equity Ratio Terhadap Return Saham.

Dari hasil uji parsial (uji t) diperoleh nilai probabilitas Debt to Equity Ratio (DER) sebesar 0.90 dan koefisien sebesar 0.007450. Nilai probabilitas lebih besar dari taraf signifikan 0.05 artinya Debt to Equity Ratio berpengaruh positif dan tidak signifikan terhadap return saham. DER yang terlalu tinggi mempunyai dampak buruk terhadap kinerja perusahaan, karena dengan tingkat uatng yang semakin tinggi berarti beban tetap perusahaan akan semakin besar dan akan mengurangi keuantungan. Dengan tingkat utang yang tinggi dan dibebankan kepada pemegang saham, tentu akan meningkatkan resiko investasi kepada para pemegang saham.

Perusahaan kosmetik dan barang keperluan rumah tangga merupakan industri yang syarat dengan resiko, terutama pada tahap eksplorasi hingga konstruksi yang memiliki ketidakpastian yang tinggi dan memerlukan modal yang sangat besar, 
karena tingkat resiko yang tinggi sehingga pihak perbankan dalam negeri kadang tidak berani memberi dukungan pendanaan bagi perusahaan yang masih dalam tahapan tersebut dan baru berani memberi pinjaman jika perusahaan telah memasuki tahap produksi.

Oleh sebagian investor DER dipandang sebagai besarnya tanggung jawab perusahaan terhadap pihak ketiga yaitu kreditor yang memberikan pinjaman kepada perusahaan. DER yang tinggi mempunyai dampak buruk terhadap kinerja perusahaan, karena dengan tingkat utang semakin tinggi berarti beban tetap perusahaan akan semakin besar dan akan mengurangi keuntungan. Dengan tingkat utang tinggi dan dibebankan kepada pemegang saham, tentu akan meningkatkan resiko investasi kepada pemegang saham. Hasil analisis ini sejalan dengan hasil penelitian terdahulu yang dilakukan oleh Malintan (2013).

3. Pengaruh Net Profit Margin Terhadap Return Saham.

Dari hasil uji parsial (uji t) diperoleh nilai probabilitas Net Profit Margin sebesar 0.08 dan koefisien sebesar 0.011818. Nilai probabilitas lebih besar dari taraf signifikan 0.05 , artinya Net Profit Margin pengaruh positif dan tidak signifikan terhadap return saham.

Hal ini menunjukkan bahwa tingkat Net Profit Margin (NPM) yang tinggi tidak memperlihatkan bahwa perusahaan mempunyai kemampuan menghasilkan laba bersih dengan presentase yang tinggi dalam pendapatan operasional sehingga tidak menarik minat investor untuk menanamkan modalnya. Hasil penelitian ini mendukung penelitian terdahulu yang dilakukan oleh Nathaniel (2009) dimana hasilnya menunjukkan bahwa Net Profit Margin tidak berpengaruh terhadap return saham.

4. Pengaruh Current Ratio (CR), Debt to Equity Ratio (DER), dan Net Profit Margin (NPM) Terhadap Return Saham.

Berdasarkan hasil uji $\mathrm{F}$
didapatkan nilai sig sebesar 0.01
dengan nilai alpha 0,05 maka
didaptkan hasil $(0,01<0,05)$ yang
artinya Current Ratio (CR), Debt to
Equity Ratio (DER), dan Net Profit
Margin (NPM) berpengaruh terhadap
return saham. Hasil penelitian ini
sejalan dengan penelitian Chadina
(2012) yang menyatakan bahwa
Current Ratio, Debt to Equity Ratio,
dan Net Profit Margin secara bersama-
sama (simultan) berpengaruh terhadap
return saham.

\section{KESIMPULAN DAN SARAN}

\section{Kesimpulan}

1. Current Ratio berpengaruh negatif dan signifikan terhadap return saham.

2. Debt to Equity Ratio berpengaruh positif dan tidak signifikan terhadap return saham.

3. Net Profit Margin berpengaruh positif dan tidak signifikan terhadap return saham.

4. Current Ratio, Debt to Equity Ratio, dan Net Profit Margin secara simultan berpengaruh terhadap return saham.

\section{Saran}

1. Bagi Penelitian Selanjutnya

Bagi penelitian selanjutnya lebih baik mencoba dengan menambah beberapa variabel lain dalam 
pengaruhnya terhadap return saham dan menambah tahun penelitian agar hasil lebih optimal. Penelitian ini merupakan internal yang ada disuatu perusahaan maka peneliti lain dapat menambah faktor eksternal seperti Earning Per Share dan Return On Equity yang memungkinkan dapat mempengaruhi return saham.

2. Bagi Perusahaan

Hasil penelitian ini menyatakan bahwa Current Ratio berpengaruh negatif dan tidak signifikan terhadap return saham, sehingga perusahaan disarankan menginformasikan nilai Current Ratio kepada investor maupun calon investor agar dapat dijadikan pertimbangan dalam pengambilan keputusan.

3. Bagi Investor dan Calon Investor

Bagi calon investor yang akan berinvestasi pada saham, sebaiknya lebih mempertimbangkan tingkat Current Ratio yang rendah. Karena variabel tersebut memiliki pengaruh negatif terhadap return saham pada perusahaan sektor Kosmetik dan Barang Keperluan Rumah Tangga di Bursa Efek Indonesia.

\section{DAFTAR PUSTAKA}

Ang, Robert. (1997). Buku Pintar Pasar Modal Indonesia. Jakarta: Media Staff.

Chadina, Ari Astiti, Ni Kadek Sinarwati dan Nyoman Ari Surya Darmawan. (2014). Pengaruh Kinerja Keuangan Perusahaan terhadap Return Saham (Studi pada Perusahaan Otomotif dan Komponen di Bursa Efek Indonesia Tahun 2010-2012). EJournal $S 1 \quad A k$ Universitas Pendidikan Ganesha Jurusan
Akuntansi Program S1.Vol. 2, No. 1, 2014.

Ekananda, Mahyus. (2015). Ekonomi Internasional. Jakarta: Erlangga.

Fahmi, Ilham. (2012). Analisis Laporan Keuangan. Cetakan ke dua. Bandung: Alfabeta.

Harahap, Sofyan Safari. (2008). Analisis kritis Laporan Keuangan. PT Raja Grafindo Persada.

Jogiyanto, Hartono. (2003). Teori Portofolio dan Analisis Investasi. Edisi Ketiga. Yogyakarta : BPFE.

Kasmir. (2008). Analisis Laporan Keuangan. Edisi Pertama. Jakarta: PT Raja Grafindo Persada.

Kusuma, Desta Rizky dan Deny Ismanto. (2012). Petunjuk Praktikum EVIEWS 6. Yogyakarta: Universitas Ahmad Dahlan.

Malintan, Rio. (2013). Pengaruh Current ratio, Debt to Equity, PER, dan ROA terhadap return saham perusahaan Pertambangan yang terdaftar di Bursa Efek Indonesia tahun 20052010. Jurnal Akuntansi Fakultas Ekonomi dan Bisnis. Brawijaya Malang.

Nathaniel, Nicky. (2009). Analisis kinerja keuangan pada perusahaan Manufaktur yang Go Public di BEI periode 2005-2009. Skripsi.

Prihantini, Ratna. (2009). Pengaruh Inflasi, Nilai Tukar, ROA, DER dan CR terhadap Return Saham industry real estate and property yang listed di Bursa Efek Indonesia periode 2003-2006. Tesis. Semarang: Universitas Diponegoro.

Rachmawan, Adib. (2011). Pengaruh rasio keuangan dan Variabel Makro Terhadap Return Saham yang diterima oleh Pemegang Saham. Tesis. Yogyakarta: UIN Sunan Kalijaga.

Sawir, A. (2009). Analisis Kinerja Keuangan dan Perencanaan 
Keuangan Perusahaan. Jakarta: PT Gramedia Pustaka Utama.

Simamora, Henry. (2000). Akuntansi (Basis Pengambilan Keputusan Bisnis). Jakarta: Salemba Empat.

Sugiyono. (2009). Metode Penelitian

Bisnis. Bandung: Alfabeta.

Widarjono, Agus. (2013). Pengantar dan Analisis Investasi. Jakarta: Ekonosia. 